\title{
Hubungan Derajat Obesitas dengan Kadar Gula Darah Puasa pada Masyarakat di Kelurahan Batung Taba dan Kelurahan Korong Gadang, Kota Padang
}

\author{
Andi Fadilah Yusran Putri ${ }^{1}$, Eva Decroli², Ellyza Nasrul ${ }^{3}$
}

\begin{abstract}
Abstrak
Derajat obesitas sebanding dengan tingkat akumulasi lemak tubuh. Peningkatan akumulasi lemak tubuh akan meningkatkan kadar gula darah puasa. Tujuan penelitian ini adalah menentukan hubungan antara derajat obesitas dengan kadar gula darah puasa pada masyarakat di Kelurahan Batung Taba dan Kelurahan Korong Gadang, Kota Padang. Jenis penelitian ini ialah observasional dengan pendekatan cross sectional study terhadap 32 orang masyarakat yang berumur 35-60 tahun di Kelurahan Batung Taba dan Korong Gadang dengan teknik pengambilan sampel berupa purposive sampling. Derajat obesitas diukur dengan metode antropometrik, berupa Indeks Massa Tubuh (IMT) menurut kriteria Asia-Pasifik, yaitu obese I (IMT $\geq 25 \mathrm{~kg} / \mathrm{m} 2$ ) dan obese II (IMT $\geq 30 \mathrm{~kg} / \mathrm{m} 2$ ). Kadar gula darah puasa diukur secara enzimatik. Hasil penelitian menunjukkan bahwa sebagian besar masyarakat obese di Kelurahan Batung Taba dan Kelurahan Korong Gadang adalah berjenis kelamin perempuan dan berprofesi sebagai ibu rumah tangga. Sebagian besar masyarakat memiliki berat badan dengan kriteria obese I dan kadar gula darah puasa dengan kriteria $D M \geq 100 \mathrm{mg} / \mathrm{dl}$. Hasil analisis dengan uji chi-square didapatkan nilai $p=1,000$ ( $p>0,05)$, berarti tidak terdapat hubungan yang signifikan antara derajat obesitas dengan kadar gula darah puasa. Kesimpulan penelitian ini adalah tidak berbeda antara kadar gula darah puasa pada obese I dan obese II pada masyarakat di Kelurahan Batung Taba dan Kelurahan Korong Gadang.
\end{abstract}

Kata kunci: obesitas, kadar gula darah puasa, indeks massa tubuh

\begin{abstract}
The degree of obesity is equal to the rate of body fat accumulation. Accumulation of body fat increases fasting blood glucose. The objective of this study was to determine the relationship of the degree of obesity and fasting blood glucose of people who live in Kelurahan Batung Taba and Kelurahan Korong Gadang, Padang City. This was an observational cross-sectional study to 32 residents of 35 to 60 years old in Batung Taba and Korong Gadang. The subjects were taken by purposive sampling method. The degree of obesity was determined by Body Mass Index (BMI) from Asian-Pacific criteria, an anthropometric method, obese I (BMI $\geq 25 \mathrm{~kg} / \mathrm{m} 2)$ and obese II (BMI $\geq 30 \mathrm{~kg} / \mathrm{m} 2)$. Fasting blood glucose were determined enzimatically. The result of this study showed that mostly obese population in Batung Taba and Korong Gadang is female, as represented by housewifes. The majority of the population is obese I and has fasting blood glucose with DM criteria $\geq 100 \mathrm{mg} / \mathrm{dl}$. As estimated by chi-square analysis, the $p$ value $=1.000(p>0.05)$ and there was no significant relationship is found between the degree of obesity and fasting blood glucose. The conclusion from this study shows there is no different between fasting blood glucose levels in obese I and obese II among the residents of Kelurahan Batung Taba and Kelurahan Korong Gadang.
\end{abstract}

Keywords: obesity, fasting blood glucose, body mass index

Affiliasi penulis 1 Pendidikan Dokter FK UNAND (Fakultas Kedokteran Universitas Andalas Padang), 2. Bagian IImu Penyakit Dalam FK UNAND/ RSUP DR. M. Djamil Padang, 3. Bagian Patologi Klinik FK UNAND/ RSUP DR. M. Djamil Padang.
Korespondensi: Andi Fadilah Yusran Putri, E-mail :

firandila@yahoo.com, Telp: 08973270511 


\section{PENDAHULUAN}

Obesitas atau biasa disebutkan sebagai kegemukan didefinisikan sebagai kelebihan lemak atau jaringan adiposa didalam tubuh. Seseorang dapat dikatakan obese melalui berbagai macam metode dan standar pengukuran distribusi lemak tubuh, salah satu cara adalah dengan metode pengukuran antropometrik. Klasifikasi internasional pada metode pengukuran antropometrik untuk menentukan derajat obesitas didasarkan pada Indeks Massa Tubuh (IMT). Pada klasifikasi obesitas berdasarkan Indeks Massa Tubuh menurut kriteria Asia Pasifik, obesitas terbagi menjadi dua bagian yaitu obese tingkat I (IMT $\geq 25$ $\mathrm{kg} / \mathrm{m}^{2}$ ) dan obese tingkat II (IMT $\left.\geq 30 \mathrm{~kg} / \mathrm{m}^{2}\right){ }^{1,2}$

Obesitas sudah menjadi masalah global diseluruh dunia, pada tahun 2012 World Health Organization (WHO) mengatakan obesitas sebagai worldwide epidemic yang angka kejadiannya terus meningkat. Angka worldwide obesitas meningkat dua kali lipat sejak tahun 1980. Pada tahun 2008 lebih dari 1,4 milyar penduduk dewasa (20 tahun keatas) yaitu 200 juta laki-laki dan sekitar 300 juta perempuan ialah obesitas. $^{3}$

Di Indonesia, prevalensi kejadian obesitas juga cukup tinggi. Data Riset Kesehatan Dasar (Riskesdas) tahun 2007, prevalensi obesitas umum (BB lebih dan obese) secara nasional pada penduduk dewasa adalah $19,1 \%$ dengan $10,3 \%$ ialah obese dan terdapat 14 provinsi yang memiliki prevalensi obesitas umum diatas angka prevalensi nasional. Pada tahun 2010 prevalensi obesitas umum penduduk dewasa di indonesia didapatkan meningkat berdasarkan data Riskesdas tahun 2010 menjadi $21,7 \%$ dengan 11,7\% ialah obese. .,5 $^{4}$

Prevalensi obesitas umum di Sumatera Barat menurut hasil Riskesdas Provinsi Sumatera Barat tahun 2007 adalah 16,3\% dengan 8,3\% ialah obese. Terdapat sembilan kabupaten/kota yang memiliki prevalensi obesitas umum diatas angka prevalensi provinsi, yaitu kabupaten Padang pariaman, Pasaman, kota Padang, Solok, Sawahlunto, Padang Panjang, Bukittinggi, Payakumbuh dan Pariaman. Kota Padang termasuk kedalam salah satu kabupaten/kota di Provinsi Sumatera Barat yang memiliki angka kejadian obesitas yang cukup tinggi dengan 9,0\% penduduk dewasa obese, menurut Indeks Massa Tubuh (IMT). ${ }^{6}$
Obesitas sebagai epidemi global yang angkanya terus meningkatan dari tahun ke tahun menunjukkan gambaran masalah kesehatan global yang mulai meresahkan dunia, tidak hanya itu obesitas yang menetap juga menjadi masalah klinis dengan meningkatkan resiko terjadinya berbagai penyakit degeneratif yang merupakan penyebab kematian urutan pertama di Indonesia. Penyakit degeneratif yang terjadi dapat berupa diabetes melitus tipe-2, hipertensi, dislipidemia dan penyakit kardiovaskular lainnya. ${ }^{7}$ Menurut data World Health Organization Europe, obesitas telah diperkirakan bertanggung jawab dalam 65-80\% kasus baru diabetes melitus tipe-2. Diabetes melitus tipe-2 atau penyakit degeneratif lain yang terjadi pada sebagian besar kelompok obesitas ini merupakan dampak dari resitensi insulin yang terjadi beberapa dekade sebelumnya. $^{8}$

Peranan obesitas dalam resistensi insulin dijelaskan dalam berbagai teori. Salah satu teori menyatakan bahwa jaringan lemak juga merupakan suatu jaringan "endokrin" aktif yang dapat berhubungan dengan hati dan otot (dua jaringan sasaran insulin) melalui pelepasan zat perantara yang nantinya mempengaruhi kerja insulin dan tingginya penumpukan jaringan lemak tersebut dapat berakhir dengan timbulnya resistensi insulin. Resistensi insulin yang terjadi pada kelompok obesitas kemudian mengakibatkan penurunan kerja insulin pada jaringan sasaran sehingga menyebabkan glukosa sulit memasuki sel. Keadaan ini berakhir kepada peningkatan kadar glukosa dalam darah. ${ }^{9}$

Peningkatan kadar glukosa darah yang terjadi pada keadaan resistensi insulin dapat dideteksi dan diukur melalui pemeriksaan kadar gula darah. Terdapat beberapa jenis pemeriksaan kadar gula darah yang bermanfaat dalam penilaian resistensi insulin yang terjadi pada kelompok obesitas yaitu pemeriksaan gula darah puasa dan pemeriksaan gula darah 2 jam sesudah makan, yang dalam penelitian ini digunakan metode pemeriksaan kadar gula darah puasa.

Berdasarkan teori yang ada dapat diketahui bahwa adanya suatu hubungan antara tingkat penumpukan lemak tubuh yang terjadi pada individu obesitas dengan kadar gula darah puasanya, 
sehingga berdasarkan survei pendahuluan yang telah dilakukan di dua kelurahan dari dua kecamatan di kota padang yaitu Kelurahan Batung Taba, Kecamatan Lubuk Begalung dan Kelurahan Korong Gadang, Kecamatan Kuranji, ditemukan banyaknya masyarakat yang diketahui menderita obesitas, oleh karena itu perlu dilakukan penelitian pada dua kelurahan di dua kecamatan tersebut untuk membuktikan teori yang telah ada ini.

Berdasarkan latar belakang tersebut, maka peneliti ingin meneliti "Hubungan derajat obesitas dengan kadar gula darah puasa pada mayarakat di Kelurahan Batung Taba, Kecamatan Lubuk Begalung dan Kelurahan Korong Gadang, Kecamatan Kuranji”.

\section{METODE}

Penelitian ini merupakan observasional dengan jenis cross sectional study.. Penelitian dilakukan dari Oktober 2012 sampai Maret 2013 di Kelurahan Batung Taba, Kecamatan Lubuk Begalung dan Kelurahan Korong gadang, Kecamatan Kuranji, Kota Padang.

Populasi penelitian ini adalah semua masyarakat dengan usia 35-60 tahun di Kelurahan Batung Taba dan Kelurahan Korong Gadang, sedangkan subjek yang didapat ialah 32 orang. Kriteria sampel adalah laki-laki dan perempuan yang memiliki Indeks Massa Tubuh (IMT) $\geq 25 \mathrm{~kg} / \mathrm{m}^{2}$, berpuasa 8-10 jam sebelum dilakukan pemeriksaan kadar gula darah puasa, tidak diketahui sedang hamil, tidak mengidap penyakit diabetes melitus, dan tidak sedang mengkonsumsi obat-obatan yang dapat meningkatkan atau menurunkan kadar gula darah. Variabel penelitian antara lain derajat obesitas dan kadar gula darah puasa. Data dikumpulkan melalui wawancara menggunakan kuisioner, pengukuran Indeks Massa Tubuh (IMT) serta pemeriksaan kadar gula darah puasa.

Pengolahan data dilakukan dengan cara statistik dan disajikan dalam bentuk tabel yang kemudian diambil kesimpulannya. Analisis hubungan antara variabel derajat obesitas dengan variabel kadar gula darah puasa digunakan uji Chi Square dengan tingkat kemaknaan $p<0.05$.

\section{HASIL DAN PEMBAHASAN}

\section{Derajat obesitas}

Tabel 1. Distribusi frekuensi responden berdasarkan derajat obesitas

\begin{tabular}{ccc}
\hline $\begin{array}{c}\text { Derajat } \\
\text { Obesitas }\end{array}$ & Frekuensi & $\begin{array}{c}\text { Presentase } \\
\text { (\%) }\end{array}$ \\
\hline Obese I & 22 & 68,8 \\
Obese II & 10 & 31,2 \\
\hline Total & 32 & 100 \\
\hline
\end{tabular}

Berdasarkan Tabel 1 diatas dapat dilihat bahwa ditemukan 68,8\% masyarakat memiliki derajat obesitas berupa obese I, sedangkan 31,2\% masyarakat lagi memiliki derajat obesitas berupa obese II.

\section{Kadar gula darah puasa}

Tabel 2. Distribusi frekuensi respondenberdasarkan kriteria kadar gula darah puasa

\begin{tabular}{ccc}
\hline $\begin{array}{c}\text { Kategori Kadar } \\
\text { Gula Darah } \\
\text { Puasa }\end{array}$ & Frekuensi & $\begin{array}{c}\text { Presentase } \\
(\%)\end{array}$ \\
\hline $\begin{array}{c}\text { Belum pasti DM } \\
\text { DM }^{* *}\end{array}$ & 5 & 15,6 \\
\hline Total & 32 & 84,4 \\
\hline Keterangan : * :belum pasti diabetes melitus (90-99 mg/dl) & \\
& ${ }^{* *}$ : diabetes melitus & $(\geq 100 \mathrm{mg} / \mathrm{dl})$
\end{tabular}

Berdasarkan Tabel 2 dapat dilihat bahwa $84,4 \%$ responden memiliki kadar gula darah puasa kategori DM ( $\geq 100 \mathrm{mg} / \mathrm{dl})$, sedangkan responden yang memiliki kadar gula darah puasa kategori belum pasti DM (90-99 mg/dl) sebanyak $15,6 \%$.

Berdasarkan hasil penelitian ini didapatkan bahwa sebagian besar masyarakat yang berusia 35 60 tahun di Kelurahan Batung Taba, Kecamatan Lubuk Begalung dan Kelurahan Korong Gadang, Kecamatan Kuranji memiliki kadar gula darah puasa kriteria DM ( $\geq 100 \mathrm{mg} / \mathrm{dl}$ ). Tingginya kadar glukosa darah dapat disebabkan oleh berbagai faktor salah satunya ialah obesitas. Hal ini sesuai dengan teori yang dikatakan oleh Clare-Salzler pada tahun 2007, bahwa obesitas adalah salah satu faktor resiko lingkungan yang penting dalam patogenesis diabetes melitus tipe $2 .^{9}$ 
Pada penelitian ini juga didapatkan kadar glukosa darah puasa terendah sebesar $90 \mathrm{mg} / \mathrm{dl}$ dan tertinggi 184 mg/dl. Rata-rata kadar gula darah puasa masyarakat kelurahan batung taba dan korong gadang sebesar 109,88 mg/dl.

\section{Hubungan derajat obesitas dengan kadar gula darah puasa}

Tabel 3. Hubungan derajat obesitas dengan kadar gula darah puasa

\begin{tabular}{|c|c|c|c|c|}
\hline \multirow{4}{*}{$\begin{array}{c}\text { Derajat } \\
\text { Obesitas }\end{array}$} & \multicolumn{2}{|c|}{ Kadar Gula Darah } & \multirow{4}{*}{ Total } & \multirow{4}{*}{$p$} \\
\hline & & asa & & \\
\hline & $\begin{array}{c}\text { Belum } \\
\text { pasti DM }\end{array}$ & DM & & \\
\hline & n (\%) & n (\%) & & \\
\hline Obese I & $4(18,2 \%)$ & $18(81,8 \%)$ & $22(100 \%)$ & \\
\hline Obese II & $1(10 \%)$ & $9(90 \%)$ & $10(100 \%)$ & 1,000 \\
\hline Total & $5(15,6 \%)$ & $27(84,4 \%)$ & $32(100 \%)$ & \\
\hline
\end{tabular}

Tabel 3 diatas dapat dilihat bahwa hasil analisa statistik menggunakan uji Chi Square pada penelitian ini mendapatkan nilai $p=1,000$, yang menunjukkan derajat hubungan yang sangat lemah dengan tarif signifikansi $(p>0,05)$. Dari hasil analisa uji statistik tersebut dapat disimpulkan bahwa tidak terdapat hubungan yang signifikan antara derajat obesitas dengan kadar gula darah puasa.

Pada obesitas terjadi penumpukan lemak yang berlebihan didalam tubuh. Jaringan lemak tersebut merupakan suatu jaringan endokrin aktif yang dapat melepaskan sitokin-sitokin adiposa. Sitokin adiposa ini memiliki efek proinflamasi dan juga dapat menganggu jalur persinyalan insulin yang kemudian dapat berakhir pada keadaan resistensi insulin. Resistensi insulin yang terjadi dapat menyebabkan peningkatan kadar glukosa darah. ${ }^{9}$

Penelitian ini menunjukkan bahwa tidak terdapat hubungan derajat obesitas dengan kadar gula darah puasa. Hal ini berbeda dari penelitian yang ada. Perbedaan ini dapat disebabkan oleh karena kadar gula darah puasa pada setiap individu dengan obesitas dapat dipengaruhi oleh beberapa faktor lainnya seperti pola makan, aktifitas fisik dan juga faktor genetik.

Faktor lain yang dapat menyebabkan tidak adanya hubungan yang signifikan antara derajat obesitas dengan kadar gula darah puasa pada penelitian ini adalah:

1. Jenis penelitian yang digunakan adalah cross sectional study yaitu pengambilan data resiko dan efek dilakukan pada saat yang bersamaan. Hal ini menyebabkan sulitnya menentukan hubungan sebab akibat antara resiko dan efek tersebut.

2. Data yang dipakai pada penelitian ini adalah data primer, berupa kuisioner dan pemeriksaan langsung kadar gula darah puasa. Pada pengisian kuisioner, data diambil berdasarkan hasil wawancara, sehingga terdapat kemungkinan bias informasi pada saat pengambilan data. Data yang didapat tergantung kepada kejujuran responden serta pemahaman responden terhadap pertanyaan yang diberikan.

3. Pengukuran derajat obesitas responden pada penelitian ini hanya menggunakan satu jenis metode pengukuran antropometrik berupa indeks massa tubuh.

\section{KESIMPULAN}

Distribusi proporsi derajat obesitas pada penelitian ini adalah sebagian besar responden memiliki IMT kriteria obese I.

Tidak terdapat hubungan antara nilai kadar gula darah puasa pada obese I dan obese II pada masyarakat di Kelurahan Batung Taba dan Kelurahan Korong Gadang.

\section{UCAPAN TERIMA KASIH}

Terima kasih kepada responden di Kelurahan Batung Taba dan Kelurahan Korong Gadang, Kota Padang, atas partisipasi dan kesediaannya dalam membantu kelancarannya penelitian ini.

\section{DAFTAR PUSTAKA}

1. Bray GA. Obesitas. Dalam: Agnes K, Mandera LL, Sadikin V, editor (penyunting). Endokrinologi Dasar \& Klinik. Edisi ke-4. Jakarta: EGC; 1998. hlm. 88696. 
2. Seidell JC, Visscher TL. Aspek kesehatan masyarakat pada gizi lebih. Dalam: Widyastuti $P$, Hardiyanti EA, editor (Penyunting). Gizi Kesehatan Masyarakat. Jakarta: EGC' 2008. hlm.203-5.

3. World Health Organization. Obesity and overweight 2012 (diunduh Januari 2013). Tersedia dari: URL: HYPERLINK http://www.who.int/en/

4. Riset Kesehatan Dasar. Laporan nasional 2007. Jakarta; 2007.

5. Riset Kesehatan Dasar. Laporan Nasional 2010. Jakarta; 2010.

6. Riset Kesehatan Dasar Provinsi Sumatera Barat. Hasil Riset Kesehatan Dasar.2007.
7. Hamid S, Trisna I. Faktor-faktor yang berhubungan dengan obesitas sentral pada wanita dewasa (3050 tahun) di Kecamatan Lubuk Sikaping. Artikel penelitian. 2008.

8. World Health Organization Europe. Diabetes: The challenge of diabetes (diunduh Februari 2013). Tersedia dari: URL: HYPERLINK www.euro. who.int

9. Clare-salzler MJ, Crawford JM, Kumar V. Pankreas. Dalam: Hartanto $\mathrm{H}$, Darmaniah $\mathrm{N}$, Wulandari N, editor (penyunting). Buku Ajar Patologi Robbins. Edisi ke-7. Jakarta: EGC; 2007. hlm. 723-4. 